\title{
PARATHYROID HYPERPLASIA IN RABBITS PRODUCED BY PARENTERAL PHOSPHATE ADMINISTRATION ${ }^{1}$
}

\author{
By TRUMAN G. DRAKE, FUILLER AIBRIGHT ANd BENJAMIN CASTLEMAN
}

(From the Departments of Medicine and Pathology, Massachusetts Gencral Hospital, Boston)

(Received for publication November 6, 1936)

From the observations of Bergstrand (1) and others $(2,3,4)$ it has become an established fact that some cases of chronic renal insufficiency are accompanied by enlargement of the parathyroid glands. The condition was well exemplified by a case recently studied at the Massachusetts General Hospital in which chronic glomerular nephritis had existed for more than twenty years, and in which necropsy revealed tremendous enlargement of all parathyroid glands (5).

The question as to the cause of the parathyroid enlargement arises. It was suggested by Albright, Baird, Cope and Bloomberg (6) that the phosphate retention in chronic renal insufficiency might be the determining factor. When the blood phosphate level is raised by intravenous phosphate administration, hypocalcemia and tetany ensue (7). It seemed not unlikely that either hyperphosphatemia or the resulting hypocalcemia might be a stimulus to parathyroid hyperplasia. The present investigations were undertaken to determine the effect of administration of parenteral phosphate on the parathyroid glands of rabbits.

\section{METHOD}

The animal selected was the rabbit because the veins are easily accessible, and the inferior parathyroids are readily identifiable. These rabbits were fed the ordinary laboratory diet of oats, carrots, and hay. Most of the animals had been used from one to several weeks previously for the Friedman modification of the Aschheim-Zondek test (8), but several males and previously unused females were included in the control and experimental groups.

For injection, a buffered solution of sodium phosphate was prepared. The stock solution was made up as follows.

1 This investigation was made possible by a grant from the Proctor Fund of the Harvard Medical School.
$\mathrm{NaH}_{.2} \mathrm{PO}_{4} \ldots \ldots \ldots \ldots \ldots \ldots \ldots \ldots$ grams

$\mathrm{NaOH} 2.5 \mathrm{~N} \ldots \ldots \ldots \ldots \ldots \ldots \ldots .410$ cc.

Distilled water up to ........ $850 \mathrm{cc}$.

Then $43.93 \mathrm{cc}$. of this concentrated solution was diluted to $500 \mathrm{cc}$. with distilled water producing a solution of $\mathrm{pH} 7.3$ isotonic with the blood, and containing $25 \mathrm{mgm}$. of inorganic phosphorus per $10 \mathrm{cc}$. The solution was prepared in chemically clean glassware and, after autoclaving, was kept in a refrigerator to prevent growth of possible contaminants, especially molds.

In most cases the animals were injected three times a day intravenously, the quantity usually being $10 \mathrm{cc}$. (=25 mgm. P) each time. Some of the rabbits were given additional subcutaneous injections in $10 \mathrm{cc}$. doses. At varying intervals the animals were sacrificed and autopsied. This included the removal and immediate weighing on a micro balance of the inferior parathyroid glands.

TABLE I

Experimental group

\begin{tabular}{|c|c|c|c|c|c|c|}
\hline \multirow{2}{*}{$\begin{array}{c}\text { Rabbit } \\
\text { serial } \\
\text { number }\end{array}$} & \multirow{2}{*}{ Weight } & \multirow{2}{*}{$\begin{array}{c}\text { Weight } \\
\text { of inferior } \\
\text { para- } \\
\text { thyroids }\end{array}$} & \multirow{2}{*}{$\begin{array}{l}\text { Number } \\
\text { of days } \\
\text { injected }\end{array}$} & \multicolumn{3}{|c|}{ Number of injections } \\
\hline & & & & $\begin{array}{l}\text { Intra- } \\
\text { venous }\end{array}$ & $\begin{array}{l}\text { Subcu- } \\
\text { taneous }\end{array}$ & Total \\
\hline $\begin{array}{r}902 \\
746 \\
903 \\
835 \\
707 \\
643 \\
829 \\
683 \\
7 \\
1 \\
837 \\
901 \\
602 \\
11 \\
987 \\
991 \\
1000 \\
738 \\
710\end{array}$ & \begin{tabular}{|l|} 
kgm. \\
1.8 \\
2.5 \\
1.9 \\
2.5 \\
1.6 \\
2.55 \\
2.5 \\
2.0 \\
1.85 \\
1.55 \\
1.7 \\
2.15 \\
2.1 \\
1.8 \\
2.1 \\
2.1 \\
1.9 \\
2.0 \\
2.25 \\
Averag
\end{tabular} & \begin{tabular}{|c|c} 
mgm. \\
22 \\
45 \\
23 \\
35 \\
35 \\
$*$ \\
25 \\
24 \\
7 \\
9 \\
18 \\
14 \\
$*$ \\
7 \\
11 \\
13 \\
10 \\
25 \\
17.5 \\
20
\end{tabular} & $\begin{array}{r}108 \\
80 \\
56 \\
54 \\
49 \\
33 \\
28 \\
22 \\
21 \\
20 \\
17 \\
16 \\
15 \\
8 \\
7 \\
7 \\
7 \\
2 \\
1\end{array}$ & $\begin{array}{r}324 \\
240 \\
168 \\
162 \\
147 \\
99 \\
84 \\
66 \\
63 \\
60 \\
51 \\
48 \\
45 \\
24 \\
21 \\
21 \\
21 \\
6 \\
4\end{array}$ & $\begin{array}{r}215 \\
32 \\
59 \\
53 \\
0 \\
0 \\
5 \\
0 \\
63 \\
60 \\
0 \\
0 \\
0 \\
24 \\
21 \\
21 \\
21 \\
0 \\
0\end{array}$ & $\begin{array}{r}539 \\
272 \\
227 \\
215 \\
147 \\
99 \\
89 \\
66 \\
126 \\
120 \\
51 \\
48 \\
45 \\
48 \\
42 \\
42 \\
42 \\
6 \\
4\end{array}$ \\
\hline
\end{tabular}

* Hyperplasia (not weighed). 


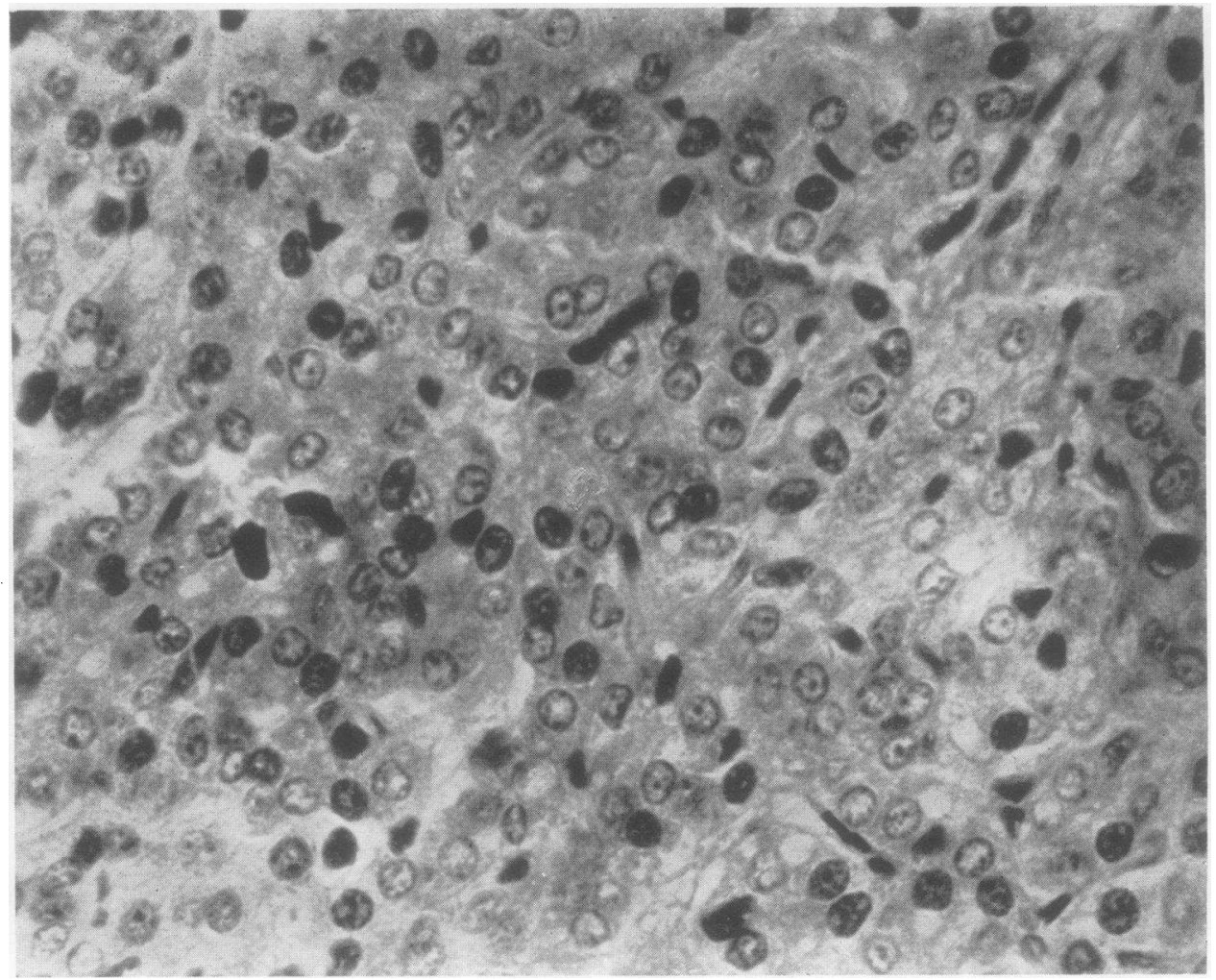

禹密

< 항

녕 용

艺究

式

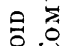

눈

空

i

范

엘 $\mathrm{z}$

望要客

要迹㝴

눙

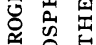

焉

웅

要专

《

人

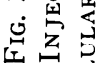

点空

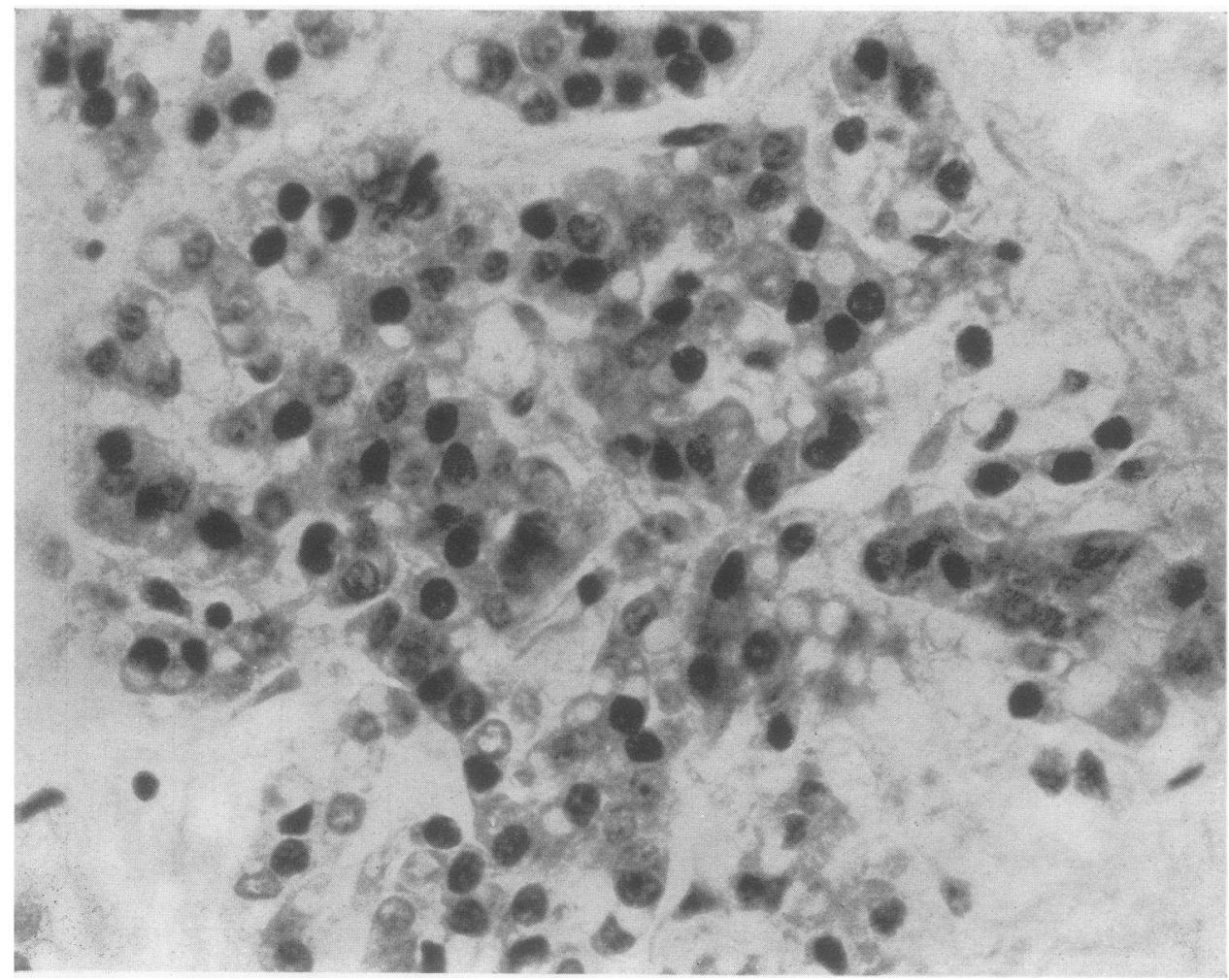

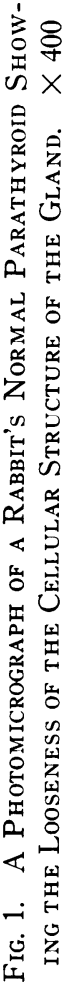


The superior pair were disregarded because they are usually small and are buried within the substance of the thyroid gland.

\section{RESULTS}

Tables I and II indicate the results obtained in the experimental and control groups.

\begin{tabular}{|c|c|c|c|}
\hline $\begin{array}{c}\text { Rabbit } \\
\text { serial } \\
\text { number }\end{array}$ & Weight & $\begin{array}{c}\text { Weight } \\
\text { of inferior } \\
\text { parathyroids }\end{array}$ & $\begin{array}{l}\text { Number of days } \\
\text { in our } \\
\text { animal farm }\end{array}$ \\
\hline $\begin{array}{r}905 \\
978 \\
892 \\
\mathrm{C} \\
10 \\
907 \\
898 \\
992 \\
900 \\
995 \\
\mathrm{~A} \\
\mathrm{E} \\
946 \\
\mathrm{~B} \\
12 \\
\mathrm{D} \\
883 \\
915 \\
837\end{array}$ & $\begin{array}{l}\text { kgm. } \\
2.8 \\
2.2 \\
2.1 \\
2.0 \\
2.0 \\
2.0 \\
2.0 \\
1.95 \\
1.9 \\
1.85 \\
1.8 \\
1.75 \\
1.75 \\
1.7 \\
1.7 \\
1.65 \\
1.6 \\
1.45 \\
?\end{array}$ & $\begin{array}{c}\text { mgm. } \\
20 \\
10 \\
7 \\
8 \\
19 \\
7 \\
12 \\
12 \\
21.4 \\
12 \\
8 \\
12.5 \\
23 \\
7 \\
6 \\
12.5 \\
17 \\
14.8 \\
18 \\
\text { rage } 13\end{array}$ & $\begin{array}{c}110 \\
21+ \\
? \\
10+ \\
9 \\
? \\
? \\
21+ \\
23+ \\
46+ \\
30 \\
? \\
4+ \\
60 \\
15 \\
? \\
13+ \\
3+ \\
2+\end{array}$ \\
\hline
\end{tabular}

There were 19 rabbits in each series which would seem to be enough to permit of valid conclusions. The average weight of the animals was approximately 2 kilograms. Normally there is no correlation between the weight of the animal and the combined weight of the inferior parathyroids.

The glands of the injected group averaged more than 50 per cent heavier than those of the control animals, and this figure would be considerably higher if only those animals injected over three weeks were included. The heaviest glands in the experimental group weighed about twice the maximum observed in the control group.

\section{HISTOLOGICAL STUDIES}

Microscopic studies of the glands leave no doubt as to the effect of the phosphate injections on the parathyroids of the experimental group. The slides of both the control and experimental animals were mixed together and one of us (B. C.) was able to differentiate between the two groups in 80 per cent of the cases. Difficulty in recognizing hyperplasia was encountered in only a few cases-those injected for 7 to 8 days. The rabbit injected for one day (Number 710) showed definite hyperplasia in three-fourths of the gland; Number 738, injected for two days, showed generalized hyperplasia.

The normal rabbit parathyroid (Figure 1) is composed predominately of chief cells very loosely grouped together. The intervening stroma gives the impression of being slightly edematous and quite vascular. There is no definite architecture although in some places there is a slight tendency to pseudo-acinar arrangement around small blood vessels. The striking feature to keep in mind is the looseness of structure and the relative nonapposition or non-contiguity of cells. In addition, there are occasional single oxyphil cells.

In sharp contrast the parathyroid gland in the experimental group (Figure 2) shows a definite increase in the number of chief cells. The loose architecture has disappeared. The edematous appearing non-cellular areas are filled in with apparently newly formed parathyroid cells. The blood vessel walls, except for the large vessels, have been compressed by this increased cellularity so that they appear as narrow channels, and all tendency to acinar arrangement has been obliterated. The appearance is that of a very densely packed mass of cells. Measurements of the size of the cells show practically no increase over the normal, so the process is one of hyperplasia rather than hypertrophy. A very occasional mitotic figure is seen and almost no oxyphil cells are found.

Microscopic and $x$-ray examination of the bones shows no difference between the two groups, and there is no evidence of a rachitic process that might produce a secondary parathyroid hyperplasia. The kidneys and other organs appeared normal.

\section{SUMMARY AND CONCLUSIONS}

1. The average weight of the inferior pair of parathyroid glands of 19 control rabbits was 13 mgm.; the corresponding figure for 19 rabbits which had received injections of parenteral phosphate three times daily for 1 to 108 days was $20 \mathrm{mgm}$.

2. The parathyroid glands of the injected ani- 
mals showed definite histological evidence of hyperplasia.

3. The findings support the hypothesis that phosphate retention is the cause of the parathyroid hyperplasia in cases of chronic renal insufficiency; it will require further studies to show whether the hyperphosphatemia causes the hyperplasia directly, or indirectly by producing a hypocalcemia.

Acknowledgment is made of assistance by Dr. Hirsh W. Sulkowitch in calculating the formula for a proper phosphate solution, and to Dr. Tracy B. Mallory for preparation of the photomicrographs.

\section{BIBLIOGRAPHY}

1. Bergstrand, H., Parathyreoideastudien. II. Uber Tumoren und hyperplastische Zustände der Nebenschilddrüsen. Acta med. Scandinav., 1921, 54, 539.

2. Hubbard, R. S. and Wentworth, J. A., A case of metastatic calcification associated with chronic nephritis and hyperplasia of the parathyroids. Proc. Soc. Exper. Biol. and Med., 1921, 18, 307.

3. Pappenheimer, A. M. and Wilens, S. L., Enlargement of the parathyroid glands in renal disease. Am. J. Path., 1935, 11, 73.

4. Shelling, D. H. and Remsen, D., Renal rickets. Report of a case showing four enlarged parathyroids and evidence of parathyroid hypersecretion. Bull. Johns Hopkins Hosp., 1935, 57, 158.

5. Albright, F., Drake, T. G. and Sulkowitch, H. W., Renal osteitis fibrosa cystica. Report of a case with discussion of metabolic aspects. (In press.)

6. Albright, F., Baird, P. C., Cope, O. and Bloomberg, E., Studies on the physiology of the parathyroid glands. IV. Renal complications of hyperparathyroidism. Am. J. M. Sc., 1934, 187, 49.

7. Binger, C., Toxicity of phosphates, in relation to blood calcium and tetany. J. Pharmacol. and Exper. Therap., 1917, 10, 105.

8. Friedman, M. H. and Lapham, M., Simple, rapid procedure for laboratory diagnosis of early pregnancies. Am. J. Obst. and Gynec., 1931, 21, 405. 